\title{
OS PRESENTES DE OXUM: \\ SENTIDOS DA MUSEALIZAÇÃO NO TERREIRO DO GANTOIS
}

\section{THE GIFTS OF OXUM: \\ THE MEANINGS OF MUSEALIZATION AT TERREIRO DO GANTOIS}

\section{Maria Paula Adinolfi}

maria.adinolf@iphan.gov.br

Mestre em Antropologia Social pela Universidade de São Paulo

Antropóloga/Técnica em Ciências Sociais do IPHAN/BA.

ORCID: https://orcid.org/0000-0001-7001-8730

\section{Mattijs van de Port}

m.p.j.vandeport@uva.nl

Doutor em Antropologia Cultural

Professor da Faculdade de Ciências Sociais e Comportamentais da Universidade de Amsterdam.

ORCID: https://orcid.org/0000-0003-3664-971X

\section{RESUMO}

Este artigo discute como os aposentos de uma famosa sacerdotisa do candomblé foram transformados em um local patrimonializado. O Memorial de Mãe Menininha do Gantois mostra que o museu pode ser entendido como uma "linguagem" específica de status e prestígio. Esse lugar, portanto, permite refletir sobre o que acontece quando novos atores na esfera pública se apropriam e transformam essa linguagem. Embora as dimensões profanas da musealização sejam evidentes, argumentamos que, no caso deste memorial, esse processo não diminui a natureza sagrada desse sítio, mas a articula de uma nova maneira.

Palavras-chave: musealização; patrimônio cultural; candomblé.

\section{ABSTRACT}

This article discusses the way in which the living quarters of a famous candomblé priestess were turned into a heritage site. The Memorial de Mãe Menininha do Gantois shows that the form of the museum might be understood as a particular "language" of status and prestige. The site therefore allows us to discuss what happens when new actors in the public sphere appropriate and transform this language. Although the profane dimensions of musealization are hard to miss, we argue that in the case of this memorial this process does not at all diminish the sacred nature of this site, but actually articulates it in a new way.

Keywords: musealization; cultural heritage; candomblé. 
Este artigo $^{1}$ discute a maneira como a morada da famosa Iyalorixá do candomblé baiano, Mãe Menininha do Gantois, foi transformada em um local patrimonializado. O Memorial de Mãe Menininha do Gantois demonstra que o museu, enquanto forma cultural, pode ser compreendido como uma "linguagem" de status e prestígio. Esse lugar nos permite discutir o que ocorre quando novos atores na esfera pública se apropriam e transformam a linguagem da musealização. Ao passo que as dimensões profanas da musealização são evidentes, nós argumentamos que tal linguagem, no caso deste memorial, não diminui a natureza sagrada do local, mas na verdade a articula de uma nova maneira.

À primeira vista, a sala de entrada do Memorial poderia ser o quarto de qualquer pessoa de classe média ou média baixa da Bahia. Um pequeno quarto, como piso de cerâmica avermelhada, bem limpo e polido. Paredes pintadas de branco. Uma pequena janela, coberta por uma cortina que permite a entrada da luz do dia, mas impede a visão a partir de fora. Uma cama de solteiro de madeira escura, de estilo antigo, coberta com uma colcha de renda branca e decorada com uma almofada, coberta com tecido de renda amarelo-dourado. Próximo à cama, um pequeno sofá de tecido xadrez. Duas mesinhas próximas à cama, uma quadrada e baixa, coberta com uma toalha de crochê branca, sobre a qual um conjunto de jarro branco e bacia de porcelana foi colocado. Outra, redonda e mais alta, coberta com um pano branco de bordado richelieu, com seus colares de contas sagradas. Junto à parede da esquerda se situa uma cômoda também de madeira escura com gavetas, que serve como uma espécie de altar, sobre a qual foram colocadas várias estátuas de santos católicos. A decoração inclui rosas de plástico; retratos pendurados em lugares aparentemente aleatórios; uma reprodução de uma pintura barroca de Jesus crucificado; dois rosários de madeira escura, também pendurados na parede. Outros objetos que se vê são um despertador; uma xícara elegante de porcelana; um rádio a pilha antigo. De fato, este poderia ser o quarto de qualquer pessoa.

Trata-se, no entanto, do quarto da finada Mãe Menininha, a mais famosa sacerdotisa do candomblé baiano. Em 1992, ele foi transformado no Memorial Mãe Menininha do Gantois, e em 2002 o Terreiro do Gantois (Ilê Iyá Omin Axé Iyá Massê), onde o memorial se situa, foi reconhecido como patrimônio, ao ser tombado pelo Instituto do Patrimônio Histórico e Artístico Nacional (IPHAN).

O fenômeno de transformar a morada de "pessoas extraordinárias" em memoriais e museus é, obviamente, conhecido. Em todo o mundo, escritórios de líderes políticos importantes, ateliês de pintores renomados e casas onde escritores escreveram seus romances famosos têm sido "abertos ao público". Uma visita a esses locais é invariavelmente projetada como uma possibilidade de se encontrar com o cotidiano de figuras históricas; sentir o sabor da atmosfera mundana da grandiosidade; de se deparar com o que Richard Dyer uma vez chamou de "ordinariedade 
extraordinária”. A discussão feita por Dyer sobre estrelas do cinema e celebridades da mídia é relevante para compreender os memoriais de famosos:

Celebridades são uma questão de aparência - tudo que sabemos sobre elas é o que vemos e ouvimos falar. No entanto, toda a construção da mídia sobre elas nos encoraja a pensar em termos de "realmente" - como [Joan] Crawford realmente é? Qual biografia, qual história de boca a boca, que momento de qual filme revela como ela realmente é? O fenômeno das estrelas reúne tais aspectos da existência humana contemporânea, entrelaçados com a questão do 'realmente' (DYER, 1986, p. 2 , tradução nossa).

Casas transformadas em memoriais lidam com essa busca do "real" da figura venerada. Elas permitem uma visita aos bastidores da vida das celebridades, aos lugares por trás da cena da vida pública, onde as pressões para performar papéis socialmente aceitáveis diminui e as pessoas podem "ser elas mesmas". Como Erving Goffman e outros já arguiram, é nos bastidores da vida pública que a imaginação social possibilita um encontro com o "verdadeiramente real" de alguém. Posicionados na encruzilhada entre o cotidiano mundano e os processos de patrimonialização, memoriais como o de Mãe Menininha do Gantois transformam o cotidiano em um espetáculo.

Este artigo tem dois objetivos. Primeiramente, argumentaremos que estes sítios oferecem excelente oportunidade para estudar as "linguagens" em que se dá a produção de patrimônios, e por tal razão neologismos como "musealização" (musealization) (GOB, 2009; LIEFOOGHE, 2011; MULLER, 1999; NELLE, 2009) e "museificação" (museification) (DELLIOS, 2002) foram cunhados. A história do Memorial de Mãe Menininha em particular nos oferece uma visão do que ocorre quando novos atores na esfera pública se apropriam e transformam a linguagem da musealização. Em segundo lugar, dado que o memorial se refere a uma sacerdotisa e está inserido em um terreiro, mostraremos de que forma a linguagem da musealização - com suas dimensões evidentemente profanas, contudo - não diminui a natureza sagrada do sítio, mas a articula de uma nova maneira.

\section{MUSEALIZAÇÃO: O MUSEU COMO LINGUAGEM DA FORMAÇÃO DE PATRIMÔNIOS}

Museus têm sido interpretados como instituições onde ocorrem práticas como seleção, coleção e exibição de objetos valiosos e onde especialistas são encarregados de inseri-los nos cânones nacionais (e mundiais) da cultura. Neste artigo vamos abordar o museu de uma forma diferente: vamos tomá-lo como uma forma de expressão, um modo particular de registro ou representação, um meio, uma linguagem. Museólogos 
usam termos como musealização ou museificação para se referir às práticas estéticas que dotam objetos e sítios com qualidades semelhantes às de museus, e atribuem os valores associados aos museus a tais objetos e sítios. Assim, Dellios afirma que:

A museificação é um processo que, ao tempo em que se origina no museu, não é restrito a ele. No meio interpretativo da museificação, tudo é um potencial "artefato" - sejam vilas inteiras ou abstrações como "etnicidade" e "nação", ou seres humanos (DELLIOS, 2002, p. 1).

Nelle (2009), discutindo a musealização de cidades patrimônio da humanidade na América Latina, torna claro que a mera evocação da noção de museu suscita todos os tipos de valores associados a ele - tanto os positivos, como "prestígio" e "excelência de qualidade", como os negativos, tais como "gentrificação", "disneyzação" e "mortificação".

As qualidades particulares da forma de expressão representada pelo museu estão intrinsecamente ligadas - e ainda marcadas pelo - papel histórico do museu no projeto de civilizar e moralizar as sociedades. Como instituições públicas, os museus sempre foram - e ainda são - locais de produção de valor de uso e de troca. Tudo o que está em exibição em um museu é definido pelos especialistas como algo que "importa" para o público em geral (SCOTT, 2010). Além disso, o museu procurou educar e disciplinar as classes populares, induzindo comportamentos e atitudes "corretos" em relação aos objetos valiosos que exibiam. O museu, na perspectiva mais clássica dessa instituição, adota a linguagem das elites: não apenas no seu conteúdo - nos objetos e tópicos relacionados que considera dignos de atenção e valoração - mas também no modo como compõe e exibe seu acervo, no tipo de relação que estabelece entre objetos e visitantes, o tipo de comportamento que impõe ao visitante, o tipo de comportamento que considera aceitável e inaceitável. Portanto, apresentar a morada de pessoas famosas na "linguagem" do museu é dar destaque ao que é ordinário e imbuí-lo de uma aura de extraordinariedade.

Claramente, como uma linguagem de prestígio, a musealização é eminentemente política e amplamente reconhecida como tal. Os estudiosos discutiram a importância dos museus na formação da esfera pública burguesa (BARRET, 2011; BENNET, 1995; FOUCAULT, 1977) apontaram seu papel na expansão dos impérios coloniais, onde os museus sinalizavam a superioridade do homem branco e se tornaram um dispositivo estratégico para mostrar seu poder sobre as colônias (BARRINGER E FLYNN, 1998; COOMBES, 1995).

Portanto, não é de surpreender que os poderes da musealização não sejam apenas buscados e desempenhados por estados e governos, mas cada vez mais por grupos subalternos - e até indivíduos - que buscam reafirmar e ascender sua posição na sociedade. De acordo com MacDonald e Fyfe, em todos os lugares tem havido "uma 'museificação' de cada vez mais aspectos da cultura e uma reivindicação do museu por 
cada vez mais setores da sociedade" (MACDONALD; FYFE, 1996, p. 2, tradução nossa).

Mais relevantes para o nosso caso são as tentativas de grupos anteriormente desprivilegiados (nações periféricas, minorias étnicas e raciais, residentes de bairros de classe baixa, membros de comunidades religiosas minoritárias) dentro do Estado-Nação de se apropriar e incorporar o idioma do museu em suas lutas pela emancipação política. $\mathrm{O}$ que nos leva de volta ao Memorial da Mãe Menininha do Gantois.

\section{CANDOMBLÉ E O MUSEU: DE SER EXIBIDO A EXIBIR-SE}

Muitos autores notaram o interesse público de longa data no candomblé. Apresentada como um exemplo do "primitivo" e do "africano", essa religião atraiu tanto atenção negativa como positiva. As autoridades da Igreja e do Estado - determinadas a estabelecer uma "ordem civilizada" em solo brasileiro - perseguiram sacerdotes, adeptos e "curandeiros", invadiram terreiros e destruíram ou confiscaram objetos sagrados. A partir de 1920, no entanto, a vanguarda intelectual e artística modernista, fortemente influenciada por críticas surrealistas ao ideal da civilização e pela moda parisiense da "negrofilia", começou a apontar o candomblé como um exemplo genuíno, puro e autêntico do patrimônio afro-brasileiro. O nacionalismo cultural do governo Vargas (19351945, 1950-1954), que redefiniu a "brasilidade" em termos da mistura das "três raças", promoveu essa apreciação da cultura negra (incluindo, embora ambivalentemente, o candomblé) como uma das fontes constitutivas da identidade brasileira.

Posteriormente, o avanço da emancipação da população afro-brasileira e a crescente influência dos movimentos negros promoveram uma qualificação positiva do candomblé enquanto "cultura". Nesse processo, a dimensão "perigosa" do candomblé, como suas interações com o que foi descrito como "magia negra", foi minimizada. Além dos muros dos terreiros, os orixás se tornaram emblemas do Afro-Brasil, além de agentes espirituais ativos que desempenham seus papéis na vida dos indivíduos. As festas com transe de possessão começaram a ser qualificadas como "danças coloridas", "música emocionante e primitiva" e "folclore afro-brasileiro", ao invés de cerimônias religiosas que existem para permitir a chegada dos deuses (VAN DE PORT, 2007).

A presença do candomblé nos museus brasileiros acompanha de perto essas transformações. Os chamados "museus da Polícia" e de Medicina Legal foram as primeiras instituições a exibir objetos do candomblé: itens confiscados da cultura material das religiões afro-brasileiras foram expostos como exemplos da "patologia" da raça negra (MAGGIE, 1979, 1992; SANSI-ROCA, 2007; SERRA, 2006). Logo, porém, objetos de candomblé também apareceram em museus folclóricos como espé- 
cimes da "cultura popular" e o legado histórico de afrodescendentes no Brasil. A partir da década de 1980, coleções de candomblé foram exibidas em museus dedicados especificamente à história e cultura da população afro-brasileira. O surgimento dos museus afro - especificamente, o Museu Afro-Brasileiro da Universidade Federal da Bahia (UFBA), em Salvador, e o Museu Afro-Brasil, em São Paulo - expressou contradiscursos cada vez mais influentes na esfera pública, que buscam redefinir a história do Brasil destacando os horrores da escravidão e a contínua repressão e discriminação da população negra no Brasil.

Esses museus exibiram o candomblé de acordo com seus próprios enquadramentos ideológicos. Todos eles também reconheceram o candomblé como uma formação religiosa, embora essa religiosidade tenha sido articulada de maneira diferente em diferentes épocas: de "superstição" e "magia negra" nos museus da Polícia e de Medicina Legal a "crenças populares" em museus folclóricos, a "religião de matriz africana" nos museus da cultura e história afro-brasileiras. O principal enquadramento do candomblé, no entanto, foi como patrimônio - o legado cultural dos africanos escravizados e seus descendentes em solo brasileiro.

A partir da década de 1990, os adeptos do candomblé começaram a construir seus próprios museus e espaços memoriais dentro de seus terreiros. Depois que o Terreiro do Gantois abriu o memorial de Mãe Menininha, o prestigiado terreiro Ilê Axé Opô Afonjá inaugurou o museu Ilê Ohun Lailai, seguido por outros na Bahia (Memorial Lajoumin, no Terreiro Pilão de Prata; Memorial Mãe Mirinha do Portão, no Terreiro São Jorge da Goméia; Memorial Kisimbiê, no Terreiro Mokambo; e Memorial Unzó Tombenci Neto, no Terreiro Matamba Tombenci Neto), em Pernambuco (Museu Severina Paraíso da Silva, também conhecido como Memorial Xambá, no Portão do Gelo) e no Rio de Janeiro (Memorial Iyá Davina no Ilê Omolu Oxum). Esse processo significou uma mudança significativa na política de representação do culto: passou de ser exibido por pessoas de fora como um "outro" criminalizado, patologizado, folclorizado ou etnologizado para um "autorretrato" do candomblé na forma de museu.

A criação desses espaços de exposição não é um evento isolado, mas parte de uma ação mais ampla, dentro dos circuitos do candomblé, de recuperar sua própria voz na esfera pública, onde cada vez mais pessoas de fora estão produzindo imagens e narrativas sobre o que é, poderia ou deveria ser o candomblé (PARÉS, 2012; SANTOS, 2005; VAN DE PORT, 2011). Assim, sacerdotes e adeptos têm resistido ao uso (ou, como eles chamariam, à profanação) de símbolos e imagens do candomblé na esfera pública, mais notoriamente em seus processos judiciais contra o uso de símbolos sagrados do candomblé em desfiles de carnaval, e em suas críticas contínuas aos balés folclóricos que realizam as danças sagradas em um palco de teatro. Particularmente relevante para o nosso caso é a contestação da presença de objetos sagrados em 
museus da polícia e de medicina legal, como o Museu Estácio de Lima, em Salvador (SANSI-ROCA, 2007; SERRA, 2006).

Essas contestações têm obtido sucesso. Os sacerdotes do candomblé são cada vez mais consultados sobre a maneira como sua religião é representada no espaço público. O diretor de marketing da empresa pública de turismo baiana Bahiatursa, por exemplo, enfatizou que a organização estava em contato frequente com sacerdotisas influentes, a fim de garantir que "abordem corretamente a dimensão religiosa" (VAN DE PORT, 2011, p. 186). O trabalho de Roger Sansi-Roca oferece outros exemplos instigantes. Ele relata que as sacerdotisas do candomblé foram convidadas a consultar o oráculo divinatório Ifá para conhecer a opinião dos orixás sobre a construção de uma série de estátuas representando as divindades do candomblé que seriam erguidas no Dique de Tororó, para comemorar o $450^{\circ}$ aniversário da cidade (SANSI-ROCA, 2007). Ele discute também uma polêmica sobre a presença de otás (pedras sagradas que materializam e presentificam os orixás) no Museu da Cidade de Salvador. No contexto religioso, essas pedras sagradas - inextricavelmente ligadas à trajetória de iniciação individual - são escondidas da vista em vasilhas rituais (ibás), mantidas nos quartos do santo, e não podem ser vistas por pessoas que não pertencem à comunidade religiosa. Neste museu, um espécime pertencente à coleção do Museu Estácio de Lima foi exposto "para todos os olhos verem". O movimento negro apresentou uma ação na justiça exigindo que a pedra fosse removida da exposição. E a direção do museu retirou, de fato, o otá da exposição, argumentando que havia recebido a informação de que se tratava de "um objeto de extremo respeito" no candomblé, que nunca é mostrado em público, portanto não tinha lugar em uma exposição e "assim foi escondido novamente" (SANSI-ROCA, 2005, p. 140).

A implantação de memoriais e museus no interior dos terreiros parece ser mais um passo nessa tentativa do povo de santo de assumir o controle da sua própria representação. O que é tão interessante sobre esse fenômeno é que, embora sua luta seja voltada para o reconhecimento do candomblé como religião (ao invés de "folclore" ou "patrimônio cultural"), eles optam aqui pela "língua estrangeira" da musealização. Como nosso caso deixará claro, isso é menos contraditório do que parece à primeira vista - de fato, do ponto de vista do candomblé, o idioma de prestígio e valor excepcional que o museu oferece e a atitude respeitosa que ele inspira ao visitante estão muito sintonizados com a maneira como as pessoas do candomblé querem se projetar para o mundo externo.

\section{O TRONO DE MÃE MENININHA}

O Memorial de Mãe Menininha do Gantois faz parte do Terreiro do Gantois, ou Ilê Axé Iyá Omim Iyá Massê, um dos terreiros mais re- 
nomados de Salvador ${ }^{2}$. Esses terreiros defendem a chamada "ortodoxia nagô", ou seja, buscam promover um retorno à "pureza" ritual das tradições africanas (mais especificamente iorubás). Durante o século $\mathrm{XX}$, esses terreiros adquiriram enorme prestígio e respeitabilidade entre intelectuais, artistas e políticos e, desde os anos de 1980, são reconhecidos como patrimônios nacionais ${ }^{3}$. Por esses motivos, eles por vezes são chamados de "candomblés de elite" na literatura especializada (PARÉS, 2012).

O primeiro registro histórico sobre o Terreiro do Gantois é de 1868, quando já estava localizado na área da qual recebeu o apelido: a colina isolada e íngreme em que está localizado, na época cercada por densa floresta, recebeu esse nome porque um comerciante de escravos de Ghent, Bélgica, possuía aquelas terras, sendo "gantois" o gentílico correspondente, em francês, aos nascidos em Ghent. Em 1922, a mais alta posição hierárquica no templo foi assumida por Maria Escolástica da Conceição Nazaré, que tinha apenas 28 anos de idade. Ela lideraria o Gantois por sessenta e quatro anos e, conhecida como "Mãe Menininha", se tornou uma lenda, popularmente reconhecida como "a maior iyalorixá do Brasil de todos os tempos".

Mãe Menininha era filha de Oxum, uma deusa maternal, cujos atributos são, entre outros, a beleza, feminilidade, fertilidade, doçura e vaidade $^{4}$. Seus domínios são os rios, lagos e cachoeiras. Amarelo e ouro são as cores de suas roupas e contas rituais. Um leque de bronze ou latão, geralmente com espelho, chamado de abebê, é a mais importante ferramenta ritual usada na dança de Oxum, durante o transe de possessão. No processo histórico do sincretismo, Oxum também foi identificada com diversas invocações de Nossa Senhora, na Bahia especialmente com a Imaculada Conceição, o que enfatiza seus atributos maternais.

Nas visões de mundo do candomblé, as pessoas possuem características das divindades às quais são consagradas. A personalidade do iniciado é construída tendo os orixás como modelos. Assim, como filha de Oxum, Mãe Menininha encarnou seus atributos. Durante sua vida, ela foi identificada progressivamente com Oxum. Muitas pessoas, por ocasião de sua morte ou na celebração póstuma de seu centésimo aniversário, referiram-se à intimidade que ela tinha com os orixás, afirmando que "ela própria era um orixá vivo".

A fama de Mãe Menininha já foi notada na conhecida etnografia de Ruth Landes, baseada em pesquisas realizadas no final da década de 1930:

Embora Mãe Menininha fosse jovem para os padrões afro-brasileiros, pois tinha quarenta e poucos anos, provavelmente era a sacerdotisa mais notável da Bahia... Todo mundo já tinha ouvido falar dela, e falava dela com respeito. Um congresso internacional de sociólogos realizou uma celebração em seu terreiro no ano anterior (onde eles serviram champanhe, Dr. Estácio me disse), e então grandes réplicas de Mãe Menininha e 
algumas sacerdotisas assistentes, como bonecos de tamanho real, foram feitas e colocadas em exibição permanente no pequeno museu anexo à Escola de Medicina (LANDES, 1947, p. 71).

Essa fama não derivou apenas de sua experiência ritual e posição legítima no Gantois, um terreiro que já possuía considerável prestígio social sob sua antecessora Mãe Pulcheria, mas também de seu carisma individual e sua capacidade de estabelecer fortes laços com intelectuais (entre eles os antropólogos autores de narrativas que pretenderam atestar a autenticidade do Gantois), artistas baianos (cruciais para a produção da "baianidade" na literatura, música e artes), além de políticos e membros das elites baianas em geral.

A partir da década de 1960, sua imagem foi amplamente divulgada pela mídia como uma doce avó negra, usando óculos de aros pretos grossos e a tradicional vestimenta de renda branca das sacerdotisas baianas. Seu nome estava nos lábios de toda a nação brasileira quando Maria Bethânia e Gal Costa chegaram às paradas com a canção de Caymmi "Oração de Mãe Menininha”, composta em 1972. Quando, nas décadas de 1970 e 1980, o governo da Bahia decidiu investir no candomblé como símbolo da baianidade por excelência, a fama de Mãe Menininha atingiu seu ápice. Ela se tornou uma lenda viva. O sociólogo Reginaldo Prandi, lembrando o período, escreveu “... foi através da música popular que aprendemos os nomes dos orixás... mas agora era necessário viajar para a Bahia para ser abençoado por Menininha; jogar os búzios para que lesse seu destino; sentir o sabor do feitiço, o verdadeiro" (PRANDI 1999, p. 132).

O quarto de Mãe Menininha, que se tornaria o memorial, figurava fortemente na sua imagem midiatizada. Durante sua vida, este quarto fora de fato um espaço multifuncional. Primeiramente, era seu quarto. De acordo com relatos de membros do terreiro, embora Mãe Menininha fosse casada, decidiu morar com as filhas carnais no terreiro, sem o marido, para cumprir com suas obrigações religiosas. À noite, as filhas desanto mais íntimas dormiam ali a seus pés. Dadas as limitações físicas e a falta de mobilidade, causadas por uma doença crônica, ela também passava a maior parte do dia neste quarto. Ele continha uma pequena cozinha e ela costumava fazer suas refeições particulares lá. O quarto era, de fato, o lugar onde toda a sua vida privada acontecia. No entanto, como uma mulher acamada, era também o lugar onde recebia todos os visitantes e jogava o oráculo dos búzios. De fato, uma breve olhada nas fotos mais famosas de Menininha revela que o quarto também era sua "sala do trono", sendo o "trono" sua pequena cama de solteiro, onde ela se sentou para receber políticos e artistas famosos, bem como pessoas muito humildes que procuravam sua ajuda.

O que essa combinação um tanto inusitada do espaço mais privado e o mais público - "cama" e "trono", "bastidores" e "palco" - ofereceu à imaginação social revela-se nos relatos das visitas de famosos baianos a Mãe Menininha. O famoso líder político baiano, Antônio Carlos Maga- 
lhães, conhecido popularmente como ACM, era um visitante frequente. ACM foi diversas vezes deputado, governador da Bahia, ministro, prefeito de Salvador e senador, e sua influência cresceu enormemente durante a ditadura militar (1964-1985). Mesmo após a redemocratização, ele continuou a governar a Bahia de forma autoritária, embora populista. Dizia-se que Magalhães era um iniciado, ou pelo menos um cliente de Mãe Menininha, e esse relacionamento entre ambos frequentemente vinha a público. Magalhães precisava da sacerdotisa não apenas para obter serviços mágico-religiosos, mas também para validar seu projeto de consolidação de uma identidade baiana mestiça, que era o suporte ideológico de suas ações populistas. Os candomblés da ortodoxia nagô, e especialmente o Gantois, se beneficiaram de sua proteção, e ele foi reconhecido como um verdadeiro baiano, identificado com as tradições religiosas de seu povo. No entanto, ACM nunca pôde falar abertamente de seu envolvimento com o candomblé, pois isso comprometeria sua posição como um homem moderno e poderoso. A natureza exata de seus vínculos com o candomblé era - e permanece sendo - um "segredo público" no sentido exato que Michael Taussig deu à expressão: "aquilo que geralmente é conhecido, mas não pode ser articulado" (TAUSSIG, 1999, p. 5). O quarto de Mãe Menininha serviu perfeitamente à articulação dessa ambivalência. Imagens de suas visitas à Iyalorixá "meramente" mostram um homem idoso visitando uma velha negra amigável e acamada: uma cena perfeitamente inocente, dando margem a todas as especulações adicionais sobre a natureza exata dessas visitas.

Outro exemplo revelador do papel que teve o quarto de Mãe Menininha na significação do candomblé é encontrado nas palavras da cantora baiana Maria Bethânia, explicando como ela se envolveu com essa religião:

Eu nunca tinha estado nos grandes candomblés da Bahia. Eu estava com medo. Um medo que me dá calafrios e que tenho até hoje. Quando Vinícius de Moraes se mudou para Salvador, ele me disse: "Não acredito que uma mulher baiana não conheça Mãe Menininha do Gantois". Então eu a conheci como artista, pois ela era minha fã, mas no momento em que entrei no terreiro e vi aquela senhora, aquela deusazinha, pensei: "Meu Deus, esse é o meu lar. É aqui que eu quero estar". E felizmente ela, uma mulher de uma sabedoria única, entendeu tudo. Ela só me mostrou beleza, delicadeza e ternura ${ }^{5}$ (Maria Bethânia).

\section{O MEMORIAL: MORADA PARA OS “PRESENTES DE OXUM”}

Após a morte de Mãe Menininha, em 13 de agosto de 1986, sua família de sangue começou a pensar em fazer um memorial em sua homenagem. A escolha de transformar a morada de Mãe Menininha - especialmente seu famoso quarto - em um memorial sem dúvida deveu-se 
à importância (mencionada acima) desse espaço na vida da sacerdotisa como figura pública e privada. No entanto, a ideia também pode ter sido moldada pelo fato de Salvador já ter alguns exemplos de espaços privados que foram musealizados e abertos ao público: o Instituto Feminino da Bahia (inicialmente uma escola para moças, depois transformado no Museu Henriqueta Catharino), as opulentas mansões coloniais de famílias baianas, como o Museu Wanderley Pinho, instalado na casa principal do engenho de açúcar Freguesia, do século XVI em Candeias, no Recôncavo Baiano, e - aquele que influenciou a formação do Memorial da Mãe Menininha mais diretamente - o Memorial de Irmã Dulce, "O Anjo Bom do Brasil", uma freira baiana que fundou um hospital e fez diversas obras sociais para a população pobre, canonizada em 13 de outubro de 2019. Todos esses museus seguiram o mesmo "formato" de dar ao público acesso à "vida como era vivida" por pessoas famosas ou pessoas que viviam em uma época histórica específica.

A Iyakekerê Angela Millet, atualmente a segunda pessoa na hierarquia do Gantois, afirmou que a comunidade do terreiro estava inicialmente preocupada com a preservação dos pertences de Mãe Menininha. Como filha de Oxum, ela era muito vaidosa e tinha centenas de roupas rituais, contas, colares, jóias e outros acessórios, especialmente uma coleção de leques. Desde o início, então, o desenvolvimento do projeto seguiu parcialmente um discurso preservacionista, exibindo preocupações museológicas típicas. Além disso, para ser validada perante a sociedade como um todo, a preservação da memória de Mãe Menininha não podia ser vista apenas como uma questão individual: tinha que ser enquadrada como a "preservação da cultura afro-brasileira" ou a preservação da memória afro-brasileira.

O memorial foi estabelecido em 1992, seis anos após sua morte. Foi uma iniciativa de sua filha carnal e sucessora, Mãe Cleuza, apoiada por sua irmã Carmem (que depois sucederia a Mãe Cleuza no trono do Gantois), filha, filhos e sobrinhas. No entanto, alguns filhos de santo do terreiro que ocupavam cargos em instituições culturais do estado também desempenharam um papel importante, mobilizando o aparato estatal para fornecer suporte técnico ao memorial. O projeto envolveu uma decisão política de Antônio Carlos Magalhães, que solicitou aos museólogos e restauradores que eram funcionários da Diretoria de Museus, então vinculada à Fundação Cultural do Estado da Bahia, que restaurassem as peças, fizessem um projeto do memorial e o implementassem. O apoio financeiro foi fornecido por Nizan Guanaes, filho de santo de Mãe Menininha e dono de uma das agências de publicidade mais bem-sucedidas do Brasil então, premiada internacionalmente e sugestivamente chamada "África".

A inauguração, em 10 de fevereiro de 1992 - o dia em que ela completaria 98 anos - foi um grande evento público. Centenas de pessoas reuniram-se dentro e fora do pequeno quarto, entre elas muitas autori- 
dades municipais, estaduais e federais, artistas, intelectuais e autoridades religiosas do candomblé. Desde então, o memorial recebe visitantes regularmente. Em uma entrevista, Nádia, uma filha de santo que é a guardiã e guia do memorial, afirmou que eles são principalmente turistas, brasileiros ou estrangeiros, e que a maioria das visitas acontece durante as férias de verão, quando a cidade está mais cheia de turistas.

Em 2010, o memorial foi reformado e uma nova museografia foi adotada. Este artigo trata principalmente da exposição original, considerando que os aspectos que focamos não mudaram muito na nova. Um olhar mais atento ao design do memorial nos permite abordar a questão de como a linguagem da musealização transformou os aposentos de Mãe Menininha e discutir qual mensagem o memorial, na montagem escolhida, transmite aos visitantes, intencionalmente ou não.

O memorial é integrado organicamente ao terreiro, e não há limites entre ele e o espaço sagrado. Para entrar, é preciso passar pelos assentamentos (complexos materiais consagrados, onde as divindades são presentificadas) de alguns orixás que ficam ao pé das árvores sagradas no pátio interno do terreiro ou entrar pelo barracão (salão cerimonial principal). Isso aumenta a impressão de entrar nos bastidores, em um ambiente íntimo. O horário de funcionamento, portanto, obedece à rotina religiosa. Qualquer ritual que deva acontecer prevalece sobre a abertura do memorial, que é simplesmente fechado ao público sem aviso prévio.

O memorial em si consiste em duas salas. A principal delas é, sem dúvida, o próprio quarto de Mãe Menininha, que já foi descrito no início deste artigo. Na verdade, é uma recriação pelos museólogos envolvidos no projeto, que tentaram ser "fiéis ao original". Assim, algumas roupas foram deixadas penduradas nas costas de uma cadeira, evocando a ideia de que "ela tinha apenas saído para tomar um banho e voltaria depois de um tempo", como disse a museóloga responsável. Claramente, o design de seu quarto foi concebido para proporcionar ao visitante um encontro íntimo, transformando-o em uma pessoa que tem o privilégio de compartilhar seu quarto privado.

Curiosamente, pessoas como Ebomi Lícia ou a Iyarobá Nilza, que na verdade passavam muito tempo nesse quarto quando Mãe Menininha estava viva, afirmaram que quase nunca vão lá. A primeira disse que ela entrou no memorial apenas uma vez, após a inauguração. A segunda também disse que o visitou apenas uma vez, acrescentando que levou mais de um ano para "ter coragem de entrar", pois ficou muito abalada com a ausência de Mãe Menininha. Comentários como esses sinalizam imediatamente as muitas camadas da percepção do memorial. Para estranhos, o memorial torna presente uma sacerdotisa desconhecida, distante e lendária. Para seus filhos de santo, é um lembrete da dolorosa ausência de uma mãe muito calorosa e próxima - mas não menos mitologizada. 
A segunda sala foi nomeada "Sala dos presentes" pelos museólogos que a montaram. Quando receberam a tarefa de organizar o memorial, ficaram impressionados com a enorme quantidade de presentes que Mãe Menininha recebeu durante sua vida - perfumes, tecidos, leques, espelhos e joias - que ela guardou cuidadosamente, às vezes sem nem abrir os embrulhos. Os museólogos decidiram que também valia a pena exibir esses itens. Nessa decisão, eles seguiam uma lógica religiosa imediatamente reconhecível pelos adeptos do candomblé, enfatizando a afiliação de Mãe Menininha ao seu orixá. A principal cerimônia dedicada à deusa Oxum é chamada "o presente de Oxum", ou "oferenda às águas", uma ocasião anual em que o povo do candomblé vai a um lago, rio ou cachoeira (e às vezes também ao mar) para fazer oferendas à deusa das águas.

Perfumes, espelhos, bijuterias douradas e flores são os itens mais recorrentes nos balaios, os grandes cestos de palha em que as oferendas são colocadas para serem levadas às águas. Dar a uma das filhas de Oxum seus objetos favoritos é feito com a intenção de obter a bênção da divindade, especialmente se essa filha é uma sacerdotisa poderosa como Mãe Menininha. Consequentemente, os objetos que Mãe Menininha havia guardado durante sua vida não eram apenas pertences pessoais, mas também oferendas rituais, destinadas a serem aceitas e recompensadas com os favores de Oxum, por meio de sua amada filha.

No entanto os museólogos também estavam seguindo uma lógica museológica ao fazer a sala dos presentes. Como técnicos que se relacionam com as elites intelectuais da Bahia e que receberam seu treinamento em museus de arte e históricos, os museólogos organizaram a coleção de Mãe Menininha da mesma maneira que outras coleções particulares de objetos pessoais são organizadas e exibidas nos museus mais prestigiados da Bahia.

Esses museus, nomeadamente o Museu Carlos Costa Pinto, o Museu de Arte da Bahia e o Museu Henriqueta Catharino, exibem coleções de pertences das famílias ricas da Bahia do século XIX, consistindo principalmente em arte decorativa, como móveis, joias, artigos de cristal, talheres, porcelana, roupas e outros itens de luxo. Eles pretendem representar o estilo de vida, a opulência e o refinado gosto burguês das elites brancas, e particularmente das famílias cujas coleções particulares foram abertas ao público. A maioria desses itens foi importada da Europa, mostrando o quanto eles tentavam imitar os estilos e modas das elites europeias e, ao mesmo tempo, marcar sua distância da enorme população negra e de qualquer coisa que pudesse evocar a "África" - exceto as joias dos escravos (joias de crioula), que também faziam parte de seu estilo de vida ostensivo, pois uma escrava doméstica bem vestida e adornada aumentava o prestígio de seu dono (MATTOSO, 1997).

A montagem da "sala de presentes" responde às aspirações do terreiro de mostrar sua adesão ao gosto da elite, bem como aos entendimen- 
tos museológicos de como deve ser uma exposição de artes decorativas e "objetos femininos". A coleção contém itens pessoais de Mãe Menininha (seus leques, sua xícara favorita, seus óculos, suas bolsas), suas medalhas de honra, seus presentes, além de suas roupas rituais, joias, contas e as ferramentas da Oxum. Não teremos aqui espaço para fazer uma análise estilística desses objetos individuais e compará-los com os encontrados em outras residências e espaços privados musealizados de Salvador. Basta dizer que existe um paralelismo óbvio em termos dos tipos de objetos selecionados e da maneira como eles são exibidos. Isso é visível na maneira como as louças são exibidas dentro da cristaleira e na maneira como os móveis da sala são dispostos; mas é ainda mais evidente na estante que exibe os objetos pessoais de Mãe Menininha, que é muito parecida com uma estante semelhante de Margarida Costa Pinto, no Museu Carlos Costa Pinto. Ambas contêm itens que revelam a graciosidade, o refinamento e o bom gosto de suas proprietárias, além de seu status e reconhecimento público.

Curiosamente, a exposição não estabelece a fronteira entre os objetos da sacerdotisa e os objetos de Oxum de maneira clara; o que de fato corresponde ao fato de que não há separação clara entre a sacerdotisa e seu orixá.

\section{HERANÇAS EM DISPUTA NA CONSTRUÇÃO DA AUTENTICIDADE}

O memorial de Mãe Menininha é um exemplar da construção do patrimônio afro-brasileiro. Faz parte de um amplo processo, em todo o país, pelo qual as práticas e formas de expressão cultural afro-brasileiras - do ofício de baiana de acarajé ao samba de roda e da capoeira à patrimonialização dos terreiros de religiões de matriz africana - passam a ser definidas como instâncias excepcionais e exemplares da cultura brasileira. "Africanidade" e "pureza" (como antítese do sincretismo) são critérios importantes para a seleção dos bens integrantes do patrimônio afro-brasileiro. Sem dúvida, é a africanidade (e não a brasilidade) que constitui a excepcionalidade desses objetos culturais aos olhos dos sujeitos tradicionalmente envolvidos no processo de patrimonialização (governo, intelectuais), e também aos dos apoiadores financeiros e visitantes.

Dessa forma, é interessante notar que o memorial é um item à parte na lista de patrimônios da cultura afro-brasileira. Tendo sido a residência de uma pessoa concreta e reconstruído para perpetuar sua memória, ele não se presta facilmente à "purificação" segundo linhas ideológicas. Em vez disso, exibe todas as complexidades e antagonismos das formas como os afro-brasileiros vivem suas vidas na sociedade brasileira. Por toda a sua "autenticidade encenada", seu esforço consciente de transformar os "bastidores" em um "palco", o quarto musealizado permanece um local completamente idiossincrático, misturando as diversas formas 
pelas quais foi enquadrado como "patrimônio". Como o povo de Gantois procurou ser fiel à pessoa única que era Mãe Menininha, o projeto do memorial produziu um "excedente" ideológico inatingível, provocando rachaduras na ideologia da pureza africana.

Aqui, em um santuário da ortodoxia nagô, com sua declarada rejeição ao sincretismo religioso ${ }^{6}$, encontramos rosários na parede, um Jesus crucificado e estátuas de santos católicos. Não há nenhum sinal dos clichês de uma "afro-estética" que surgiu na esfera pública de Salvador. Pelo contrário, no centro de um local que representa a religião das classes populares da Bahia, encontra-se uma exposição de opulência burguesa. $\mathrm{O}$ memorial mostra uma identidade afro-brasileira que compartilha valores estéticos da elite branca, em vez de se desviar deles. É testemunha da preocupação constante dos candomblés tradicionais em demonstrar sua inclusão nas convenções de bom gosto, no sentido burguês do termo, e mostra como são permeados por uma estética da opulência, que pode ser rastreada desde o período barroco, e desde então tem sido difundida na sociedade brasileira.

Isso não significa que a "herança africana" esteja ausente de suas visões ou valores de mundo, ou mesmo do memorial. Apenas indica que o povo do Gantois se recusa a abstrair suas memórias de Mãe Menininha, seguindo as linhas de uma "herança africana" conforme definida em estudos etnográficos, em museus como o Museu Afro-Brasileiro ou a estética afro propagada pelos movimentos negros. Seu desejo é perpetuar a memória de um indivíduo único e, nesse desejo, dimensões de ordinariedade e extraordinariedade, patrimônio e lembranças pessoais, iconicidade e idiossincrasia são inextrincavelmente entrelaçadas. O povo do Gantois simplesmente não está interessado em catalogar exemplos do que deveria ser a cultura material afro-brasileira. Eles só querem contar sua própria história de Mãe Menininha, que é uma história de abundância, beleza e riqueza cintilantes. Uma história completamente afinada às características de seu orixá, Oxum.

\section{CONCLUSÃO: MUSEALIZAÇÃO COMO UMA LINGUAGEM DE SACRALIZAÇÃO}

Iniciamos nossa discussão sobre o Memorial de Mãe Menininha perguntando o que acontece quando o povo do candomblé se apropria da linguagem do museu para se apresentar ao público em geral. Argumentamos que a musealização atribui prestígio e valor público a qualquer objeto, diferenciando-o como digno de atenção pública. Como tal, a musealização serve à luta do povo do candomblé para obter respeito de uma sociedade que explorou suas divindades, rituais, música e símbolos para produzir uma "cultura brasileira" a partir do patrimônio afro-brasileiro, mas que mantêm amplamente seus preconceitos e intolerância no que diz respeito às práticas religiosas do candomblé. 
A construção do Memorial de Mãe Menininha evidencia o desejo da comunidade do candomblé de tomar as rédeas da sua representação. Eles evitaram uma representação icônica da famosa sacerdotisa e quiseram preservar suas memórias da Iyalorixá que de fato conheceram. Observamos que, para a consecução desse objetivo, as pessoas do candomblé ainda se valem de vozes autorizadas, como instituições culturais do estado e especialistas em museus. No entanto, seria uma visão limitada concluir que, ao se apropriar da linguagem do museu, o povo do candomblé se tornou sujeito de uma forma de expressão hegemônica e, portanto, que não poderíamos falar de um verdadeiro "autorretrato" através [do meio] do museu.

O que mais nos chama atenção no caso do Memorial de Mãe Menininha é o quanto a linguagem do museu correspondeu aos valores religiosos do povo do Gantois. Seu desejo de comemorar Mãe Menininha pode parecer um eco dos discursos sobre celebridades contemporâneas (e esse eco certamente não está ausente do projeto), mas toda a ideia de construir um memorial para uma líder religiosa antiga e respeitada também está totalmente em sintonia com a importância atribuída à ancianidade em uma religião que tem no longo processo de iniciação a via para o conhecimento e status religiosos, bem como com a grande importância atribuída à genealogia e aos ancestrais.

Assim, argumentamos que a "sala dos presentes", com sua exibição de opulência, não apenas expressa a adesão a um estilo de vida glamoroso encontrado entre a burguesia baiana em geral (da mesma forma que sua instalação não apenas expressa uma preocupação museológica típica com a conservação de peças preciosas): do ponto de vista do candomblé, a sala de presentes é igualmente expressiva do poder acumulado da Oxum de Mãe Menininha. Por fim, o fato de que todos os exemplos de memoriais e museus de candomblé podem ser encontrados dentro de terreiros, e não fora deles, fala claramente do desejo de apresentar os objetos de memória como pertencentes a um domínio sagrado.

No caso do Memorial de Mãe Menininha, assim, não há conflito entre a linguagem potencialmente profanizadora da musealização e o sagrado. Pelo contrário, o memorial permite que o povo do Gantois articule seus valores religiosos em um idioma que é reconhecido pela - e dialoga com - a sociedade em geral. Uma sociedade à qual eles também pertencem totalmente.

\section{NOTAS}

1. Esta é uma versão com modificações do artigo publicado em língua inglesa: por Adinolfi e Van De Port (2013).

2. O Terreiro do Gantois, assim como o Ilê Axé Opô Afonjá, são originados a partir de cismas religiosos no Terreiro da Casa Branca, ou Ilê Axé Iyá Nassô 
Oká, conhecido como o primeiro terreiro da modalidade ritual chamada ketu (em homenagem ao local de origem de seus criadores, os iorubas do reino de Ketu, atualmente situado no Benim).

3. Mais precisamente, a Casa Branca foi reconhecida em 1984 e os demais terreiros foram reconhecidos a partir do final dos anos 1990.

4. Mas Oxum também é uma negociante inteligente, uma bruxa poderosa, uma mulher ciumenta que pode se tornar vingativa e cruel, e a única divindade capaz de enganar Exu. Ela guarda o segredo do jogo dos búzios e o título de Iyalode, a chefe das mulheres no mercado da cidade.

5. Entrevista publicada na Revista Marie Claire, edição 115, outubro de 2000.

6. Mãe Menininha foi uma das signatárias do famoso "Manifesto contra o sincretismo" das Iyalorixás baianas, capitaneado por Mãe Stella de Oxóssi, lançado em 12 de agosto de 1983 (CONSORTE, 2006).

\section{REFERÊNCIAS}

ADINOLFI, Maria Paula F.; VAN DE PORT, Mattijs P. J. Bed and throne. The 'museumification' of the living quarters of a Candomblé priestess. Material Religion, v. 9, n. 3, p. 282-303, 2013.Disponível em: <https:// doi.org/10.2752/175183413X13730330868915>. Acesso em: 02 jun. 2020.

BARRETT, Jennifer. Museums and the Public Sphere. Chichester: Wiley-Blackwell, 2011.

BARRINGER, Tim; FLYNN, Tom (Orgs.). Colonialism and the Object: Empire, Material Culture, and the Museum. London: Routledge, 1998. BENNETT, Tony. The Birth of the Museum. London: Routledge,1995.

CONSORTE, Josildeth Gomes. Em Torno de um Manifesto de Ialorixás Baianas contra o Sincretismo. In: CAROSO, Carlos; BACELAR, Jeferson (Orgs.). Faces da Tradição Afro-Brasileira: Religiosidade, Sincretismo, Anti-Sincretismo, Reafricanização, Práticas Terapêuticas, Etnobotânica e Comida. Rio de Janeiro: Pallas; Salvador: CEAO, 2006.

COOMBES, Annie. Reinventing Africa: Museums, Material Culture and Popular Imagination in late Victorian Edwardian England. New Haven: Yale University Press, 1995.

DELLIOS, Paullette. The Museumification of the Village: Cultural Subversion in the 21st Century. The Bulletin of the Centre for East-West Cultural and Economic Studies, v. 5, n. 1, p. 1-16, 2002.

DYER, Richard. Heavenly Bodies: Film Stars and Society. New York: Macmillan Press, 1986.

FOUCAULT, Michel. Discipline and Punish. Harmondsworth: Penguin, 1977. GOB, André. Le jardin des Viard ou les valeurs de la muséalisation. Ceroart, conservation, exposition, restauration dobjects dart (revista eletrônica), v. 4, 2009. Disponível em: <http://ceroart.revues.org/1326>. Acesso em 02 jun. 2020.

LANDES, Ruth. City of Women. New York: Macmillan Press, 1947. LIEFOOGHE, Maarten. Casa d'artisti: tra universo privato e spazio pubblico: case di artisti adibite a museo. Quaderni del Museo Vincenzo Vela, v. 5, p. 59-74, 2011. 
MACDONALD, Sharon; FYFE, Gordon (Orgs.). Theorizing Museums: Representing Identity and Diversity in a Changing World. Oxford: Blackwell Publishers, 1996.

MAGGIE, Yvonne. Arte ou magia negra? Relatório FUNARTE - Convênio CNDA. Rio de Janeiro: Mimeo, 1979.

MAGGIE, Yvonne. Medo do Feitiço: relações entre magia e poder no Brasil. Rio de Janeiro: Arquivo Nacional, 1992.

MATTOSO, Kátia M. Queirós. A opulência na província da Bahia. In: ALENCASTRO, Luiz Felipe (Org.). História da Vida Privada no Brasil. v. 2. São Paulo: Companhia das Letras, 1997.

MULLER, Michel. Musealisation, Aestheticisation and Reconstructing the Past. Journal of Architecture, v. 4, n. 4, p. 361-7, 1999.

NELLE, Anja Barbara. Museality in the Urban Context: An Investigation of Museality and Musealisation Processes. Three Spanish-colonial World Heritage Towns: Urban Design International, v. 14, n. 3, p. 152-171, set. 2009.

PARÉS, Luis Nicolau. Where Does Resistance Hide in Contemporary Candomblé? In: GLEDHILL, John; SCHELL, Patience A (Orgs.). New Approaches to Resistance in Brazil and Mexico. Durham: Duke University Press, 2012.

PRANDI, Reginaldo. Referências sociais das religiões afro-brasileiras: sincretismo, branqueamento e africanização. In: BACELAR, Jefferson (Org.). Faces da tradição afro-brasileira. Rio de Janeiro: Pallas, 1999.

SANSI-ROCA, Roger. The Hidden Life of Stones: Historicity, Materiality and the Value of Candomblé Objects. Journal of Material Culture, v. 10, n. 2, p. 139-156, 2005.

SANSI-ROCA, Roger. Fetishes and Monuments: Afro-Brazilian Art and Culture in the 20th Century. New York/Oxford: Berghahn Books, 2007. SANTOS, Jocélio. O poder da cultura e a cultura no poder: a disputa simbólica da herança cultural negra no Brasil. Salvador: Edufba, 2005.

SERRA, Ordep. Sobre Psiquiatria, Candomblé e Museus. Cadernos do CRH (UFBA), v. 19, p. 309-23, 2006.

SCOTT, Carol. Museums, the Public, and Public Value. Journal of Museum Education, v. 35, n. 1, p. 33-42, 2010.

TAUSSIG, Michael. Defacement: Secrecy and the Labor of the Negative. Stanford: Stanford University Press, 1999.

VAN DE PORT, Mattijs. Bahian White: The Dispersion of Candomblé imagery in the Public Sphere of Bahia. Material Religion, v. 3, n. 2, p. 242-72, 2007.

VAN DE PORT, Mattijs. Ecstatic Encounters: Bahian Candomble and the Quest for the Really Real. Amsterdam: Amsterdam University Press, 2011. 